\title{
Program targets undergrads to make an early start on science
}

When he was a child, Edwin Krebs, like many who grew up in the 1920s and 1930s, fooled around with chemistry sets, ham radios and aquariums. As an undergraduate at the University of Illinois, he gravitated toward a career in medicine, mostly because it seemed like a good living.

But in his fourth year as an undergraduate, Krebs dabbled in biochemistry researchand found it "a fascinating experience" that led to his "becoming a research biochemist rather than a clinician." Krebs said this in the autobiography he penned after winning the 1992 Nobel Prize in Physiology or Medicine.

Gambling that undergraduates are at the perfect age to be groomed to become the best scientific minds, the Howard Hughes Medical Institute (HHMI) on 2 October launched the first scheme of its new Science Education Alliance. The alliance aims to expand the institute's investment into science education from primarily grants to individuals and institutions to include a staffed office at HHMI's new Janelia Farm campus in Virginia.

As part of the scheme, beginning in the fall of 2008, freshmen at 12 universities will enroll in a course that starts with a bit of grubbing in the dirt and, if all goes well, ends with their names on a published paper-and maybe even a chance to name a new species.

Undergraduates who conduct research are generally thought to be more likely to choose science as a career. But solid data on this is scanty. Studies in the past five years have shown only modest gains in students' interest in scientific careers after a short stint in research.

"The kids who did it because they really wanted to do it, who thought it was fun and really got involved in the culture of research were the ones who reported higher gains in confidence and awareness," says Susan Russell, who led one such study for the US National Science Foundation.

The HHMI project will include a course that teaches students to isolate and characterize the genomes of soil bacteriophages_-viruses that infect bacteria-which are handily ubiquitous and are a rich source of new genes. Students will communicate with each other online, and each class will send a representative to a meeting at the end of the year. The institute has committed \$4 million over four years and aims to train 700 students by 2011 .

In a project at Graham Hatfull's lab at the University of Pittsburgh that inspired the HHMI scheme, some freshmen gave new species of bacteriophages fanciful names such as 'Rosebush', 'Corndog' and the mysterious 'Qyrzula'.

What makes the course appealing to students is that the research spans a range of scientific approaches, says Hatfull. Students dig in the dirt and isolate phages with basic microbiology techniques. But they also get a chance to do more abstract work, manipulating and analyzing genetic sequences on computers.

"It's a real opportunity for students to get enthusiastic," Hatfull says. "You see it in their faces, in the way they talk and [in] what they write in their notebooks."

The sequencing will be done at the US Department of Energy's Joint Genome Institute, which is also planning a separate undergraduate research project in collaboration with Argonne National Laboratory in Illinois.

Cheryl Kerfeld, who moved from the University of California in Los Angeles to head that effort, says she envisions colleges and universities 'adopting' individual microbes.

"A school would annotate an entire genome," Kerfeld says. "It would become a college mascot that can be tied to lots of principles in the undergraduate curriculum." Kerfeld is working on a software toolkit that would allow students to view and annotate genomes. So far, 12 schools, including UCLA and St. Cloud State University in Minnesota, have signed up.

Another program that engages large numbers of undergraduates in biomedical research is the Summer Internship Program in Biomedical Research at the US National Institutes of Health (NIH), where more than 1,000 students slot into NIH labs each summer to gain experience working on challenging research projects.

"Students that only do prepared lab experiences don't get a feel for what a career in science is about," says the program's director, Sharon Milgram. "They don't develop that tenacity."

Top graduate schools rarely accept students who lack research experience, Milgram notes. In a random sample of individuals with bachelor's degrees in science, technology, engineering or mathematics, half had participated in undergraduate research, according to a study published in April (Science 316, 548-549; 2007).

Lest anyone question the researchers' motives in engaging students in research, organizers are quick to note that the students are not a source of cheap labor. "Having students involved in this endeavor is not the cheapest or quickest way of doing it in terms of research," says Hatfull.

Although these schemes all focus on undergraduates, there is little information on the ideal age at which to engage students in research-but 18 may already be too late, says Russell.

"The thing that really jumped out at me was the fact that so many of the respondents in hard science became interested in science when they were kids," Russell says. "So much of the money [from] the federal government and HHMI are supporting things at the college level, and our findings suggest we need to do a whole lot more in the early grades."

Emma Marris, Columbia, Missouri 